\title{
Battle Staff Training System II: Computer-Based Instruction Supporting the Force XXI Training Program
}

\author{
Richard L. Wampler and Stephen C. Livingston \\ BDM International, Inc.
}

\section{Armored Forces Research Unit}

Barbara A. Black, Chief

U.S. Army Research Institute for the Behavioral and Social Sciences 5001 Eisenhower Avenue, Alexandria, Virginia 22333-5600

November 1998 